\title{
AN ANALYSIS OF RAW MATERIALS FOR CONCRETES AS METAL SHEETS FOR SOLAR RADIATION ABSORBER
}

\author{
N. R. Ismail ${ }^{1}$, N. Fuhaid ${ }^{2}$ \\ ${ }^{1,2}$ Mechanical Engineering Departement.Engineering Faculty. Widyagama of University \\ Jl. Taman Borobudur indah no 3,Malang,East Java,Indonesia
}

\begin{abstract}
Various researches have been made in terms of materials for absorping heat and their usages. Previous researches have not started from testing the basic materials for cast concrete, therefore it is necessary to investigate the materials as heat absorbers from the solar radiation.

In this present research, an experimental method was employed to test the basic materials for cast concrete (cement, fine and har aggregates). This study is intended to know the specific weight, cement quality, heat-affordability treatment, and test for solar radiation-heat absorption and storage.

From the research results, it can be concluded that dealing with materials, the best type of sand is that of iron sand and the the best cast stone is that of hulled cast stone. From the specific weight, heat-affordability treatment, and solar radiation-heat absorbsion and storage, the type or trademark of the best cement is that of Puger-Jmeber. It is also the case for the mortar-pressure power, heat affordability treatment, and solar radiation-heat absorption and storage.
\end{abstract}

Key Words: sand, cast stone, cement, specific weight, heat affordability, solar radiation.

\section{INTRODUCTION}

\section{Background}

A heat-absorber/collector sheet functions to absorb heat and is an important component in the solar-heat radiation absorbsion system. Various researches have been made to improve the efficiency of the application of the heat absorption.

According to [6], absorption sheets made from copper coated with black paint (doff) have a heat-absorption coefficient of 0,82 and the addition of gravels on them may increase the efficiency fo solar distillation. [4] Said that the addition of gravels on the heat-absorber in the cast concrete results in higher daily productivity and efficiency of the solar still than that without gravels. According to [5] Heat-collector in the type of cast concrete may result in higher solar still than that of copper. [2] Investigated heat absorber of cast concrete, aluminium, zinc, and copper in solar heater, and showed that heat-absorber sheets with the highest temperatur is the type of copper, with stable efficiency as heat-absorber is that of cast concrete. [3] Found that a mix of absorber sheet with the types of cast concrete consisting of the composition of cement 2 parts, fine sand 2 parts and raw aggregate (cast irons 3 part may result in the highest efficiency in heat absorption than other composition, and the heat absorber sheet with the width of $5 \mathrm{cms}$ produces the highest efficiency in in heat-absorption than that of $2.5 \mathrm{cms}, 7.5$ $\mathrm{cms}$ and $10 \mathrm{cms}$.
Based on previous researchers, cast concretes are mostly used as heat-collector. Therefore it is necessary to investigae raw materials for cast concretes such as sand, corals, and cement to improve the performance of the solar radiation-absorber sheet.

\section{REVIEW OF RELATED LITERATURE}

The heat-collector/absorber functions to absorb heat from solar radiation and is an important component in the simple system of solar distillation dan solar water heater.

\subsection{Solar Power Collectior}

Based on the intended level of temperature, the forms of heat collectors principally can be divided into two parts namely:

1. Central heat-collectors with the range of $80^{\circ} \mathrm{C}$ to $150^{\circ} \mathrm{C}$.

2. Plane sheet heat-collectors with the temperature of less than $80^{\circ} \mathrm{C}$.

\subsection{Efficiency of Plain Sheet Heat-Collector}

The value of heat-absorption ( $\alpha$ s) in the sheet absorber will maximize the efficiency of solar energy receptor. The efficiency of absorption in each period of observation $(t)$ is defined as the comparison of heat 
energy absorbed by the absorber sheet $(\mathrm{Qu})$ and the level of heat-radiation received (Gt) by the surface of the absorber sheet (Ac);

$$
\eta_{s}=\frac{Q_{u}}{A_{c} \cdot G_{T}}
$$

where $\eta \mathrm{s}$ is the efficiency of the absorber sheet, while the heat absorbed by the sheet in a certain period of time [1]:

$$
Q_{u}=m C_{p}\left(T_{p}-T_{i}\right)
$$

So that the efficiency of the aborber sheet is:

$$
\eta_{s}=\frac{m C_{p}\left(T_{p}-T_{i}\right)}{A_{c} \cdot G_{T}}
$$

where:

$\mathrm{mp}=$ the mass of absorber sheet $(\mathrm{kg})$

$\mathrm{Cp}=$ heat of the type of absorber sheet $\left(\mathrm{kJ} / \mathrm{kg} .{ }^{\circ} \mathrm{C}\right)$

$\mathrm{Tp}=$ Last temperature of absorber sheet $\left({ }^{\circ} \mathrm{C}\right)$

Ti Preliminary temperature of absorber sheet $\left({ }^{\circ} \mathrm{C}\right)$

$\mathrm{Gt}=$ Total solar radiation matahari $(\mathrm{W} / \mathrm{m} 2)$

$\mathrm{A}=$ Area of the basin $(\mathrm{m} 2)$

$\mathrm{Qu}=\mathrm{Absorbed}$ heat energy $(\mathrm{kJ})$

A maximum heat energy absorption happens if there is no loss of heat into the surrounding, namely if $\mathrm{UL}=0$, so that the level of the absorption value ( $\alpha$ s) can be determined from the point of intersection in the graphics and the axis of the efficiency ordinate $(\eta \mathrm{s})$. The relationship between the absorption efficiency value $(\eta \mathrm{s})$ and the value of $\frac{\left(T_{p}-T_{a}\right)}{G_{t}}$ is shown in the figure 1.

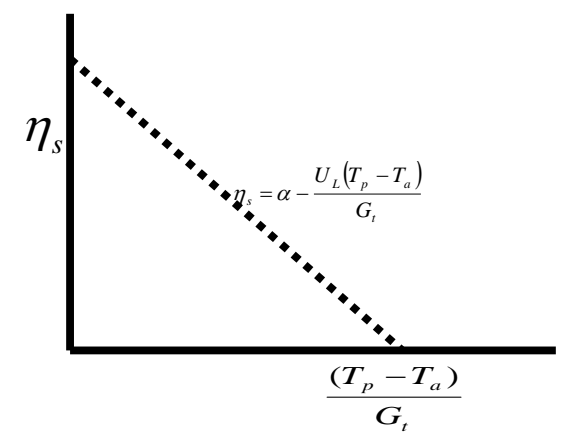

Gambar 1. Characteristics of heat-absorption efficiency (Source: Duffie dan Beckman. 1980)
Concrete is a mixture of fine and hard aggregates (sand, gravel, hulled stone, or other types of aggregates) and cement, in a certain proportion and are united with water.

\subsection{Portland Cement (PC)}

Portland Cement (PC) or called cement is a hidraulic material binder in the form of fine powders produced by refining klinkers (this material is primarily consists of calcium-cilicate with hydraulic characteristic) and gyp stines as additional materials.

The raw materials for cement are those containing lime, silica, alumina, oxida iron, and other oxidas. If the fine powers are mixed with water, they will be immediately solid. The mixture of cement and water is called cement paste, and if the paste is then mixed with sand, it will becomes cement mortar.

\section{Aggregate}

Aggregate is natural mineral grains functioning as filler materials in concrete mixtures filling almost $50 \%$ to $80 \%$ of the concrete volume, so that the characteristics and the quality of the aggregates really influence the characteristics and quality of the concrete. There are two types of aggregates, fine (sand) and hard (gravel).

1. Sand can be divided into three namely

a. Graving sand. This type of sand is usually sharp, cornered, pored and free from dangerous sal.t but this sand is often mixed with soil, so that is should be wahsed first before use.

b. River sand. It usually consists of fine and spherical grains, so that its binding power is not so good.

c. Sead sand. Its grains are fine and spherical. It contains a lot of salt, so it is not good for building

2. Gravel is distinguished into two types namely:

a. Natural, it is from natural events such as frozen aggregate.

b. Crashed iron, it is gravel from the results of chrashed stones

The easiest way to distringuish the types of aggregates is based on the size of the grains. Aggregate used in concrete is intended to save the PC, to produce high power in the concrete, to reduce the shrinkage due to ossification, tp reach solit arrangement and to control workability.

The aggregate gradation is the distribution of the measure of coarseness of aggregate grains. This gradation is obtained by making use of sieve with the hole sizes of $10 \mathrm{~mm}, 20 \mathrm{~mm}, 30 \mathrm{~mm}$, dan $40 \mathrm{~mm}$ for

\subsection{Concrete}


gravel. For sand, the hole sizes are 4,8 mm, 2,4 mm, 1,2 mm, 0,6 $\mathrm{mm}, 0,3 \mathrm{~mm}$, and $0,15 \mathrm{~mm}$.

\subsection{Water}

Water is used to enable a hydration, namely a chemical reaction between cement and water that makes the mixture solid after a certain period of time.

\section{RESEARCH METHOD}

\section{Research Stages}

Based on the background and research objectives, the research stages are presented in the Figure 2.

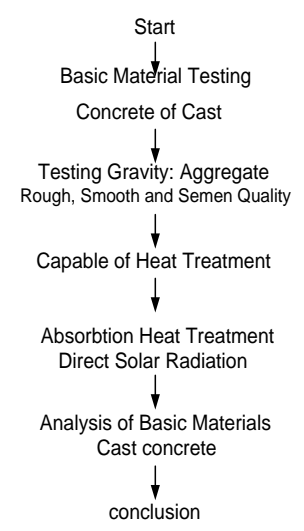

Gambar 2. Research Stages

\section{Tools}

1. The testing of solar radiation-heat absorption was made in the Solar Power and Alternative Engery Laboratory, Machine Engineering, Faculty of Engineering, Brawijaya University of Malang. . The models of testing and muasurement tools are presented in Figure 3.

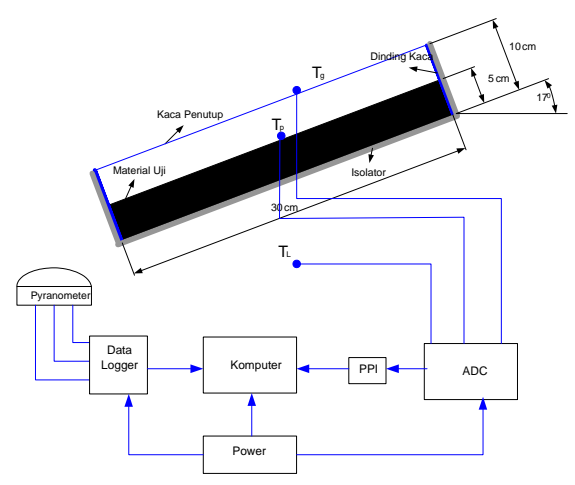

Figure3. A Schema of testing solar radiation-heat absorber

2. Heat-affordability test was made in the Metalurgy Laboratory in Unievrsity of Widyagama Malang.
3. Pressure-affordability test was made in Concrete Laboratory, Civil Engineering Department,State Polytechnique of Malang.

\section{Testing Time}

Dealing with the testing of solar radiation heatabsorption, observation were made from seven AM the next day and it directly lasted under solar exposure with the duration of data recording for each 10 minutes.

\section{RESULTS DISCUSSION}

\section{A. Testing of the Specific Weight of the Basic}

\section{Materials for Cast Concrete}

This testing was made to measure the specific weight of fine aggregate (sand), hard Aggregate (cast stone) and cement.

\section{Testing of the Specific Weight of Sand}

This testing was done to obtain the specific weight of sand, since it can influence the solidity and ability in absorbing the heat from solar radiation. Table 1 present the highest specific weight of iron sand and and the next, sand from Lumajang. Tabel 2 shows the results of the test of organic analysis, and it is redommended to use the iron sand and the sand from Lumajang as raw materials for cast concrete.

Table1 Testing of the Specific Weight of Sand

\begin{tabular}{|l|c|c|l|}
\hline \multicolumn{1}{|c|}{$\begin{array}{c}\text { Origin of } \\
\text { Sand }\end{array}$} & $\begin{array}{c}\text { Specific } \\
\text { Weight }\end{array}$ & $\begin{array}{c}\text { Absorption } \\
(\%)\end{array}$ & \multicolumn{1}{|c|}{ Explanation } \\
\hline $\begin{array}{l}\text { Sand from } \\
\text { Lumajang }\end{array}$ & 2.54 & 4.46 & $\begin{array}{l}\text { Excellent } \\
\text { Quality }\end{array}$ \\
\hline Iron sand & 4.165 & 10.2 & Too fine \\
\hline $\begin{array}{l}\text { Graving sand } \\
\text { Galian }\end{array}$ & 2.49 & 7.8 & Low Quality \\
\hline $\begin{array}{l}\text { Sand from } \\
\text { Tumpang }\end{array}$ & 2.48 & 7.65 & Low Quality \\
\hline
\end{tabular}

Table 2. An Analysis of Organic Content

\begin{tabular}{|l|l|c|c|c|}
\hline $\begin{array}{l}\text { Nam } \\
\text { e of } \\
\text { San } \\
\text { d }\end{array}$ & $\begin{array}{l}\text { Sand } \\
\text { from } \\
\text { Lumaja } \\
\text { ng }\end{array}$ & $\begin{array}{c}\text { Iron } \\
\text { Sand } \\
\text { esi }\end{array}$ & $\begin{array}{c}\text { Sand } \\
\text { from } \\
\text { Tumpang }\end{array}$ & $\begin{array}{c}\text { Graving } \\
\text { Sand }\end{array}$ \\
\hline $\begin{array}{l}\text { Expl } \\
\text { anati } \\
\text { onan }\end{array}$ & $\begin{array}{c}\text { Low } \\
\text { organic } \\
\text { content. } \\
\text { Low mud } \\
\text { layer, } \\
\text { usable }\end{array}$ & $\begin{array}{c}\text { Low } \\
\text { organic } \\
\text { content. } \\
\text { Low } \\
\text { mud } \\
\text { layer, } \\
\text { usable }\end{array}$ & $\begin{array}{c}\text { Thick } \\
\text { mud } \\
\text { layer, } \\
\text { muddy } \\
\text { solution, } \\
\text { need to be } \\
\text { cleaned }\end{array}$ & $\begin{array}{c}\text { hick mud } \\
\text { layer, } \\
\text { muddy } \\
\text { solution, } \\
\text { not good to } \\
\text { be used }\end{array}$ \\
\hline
\end{tabular}




\section{Testing of the Specific Weight of Cast Iron}

This testing was done to obtain the specific weight of cast iron, since this weight will influence the ability to absrob heat from solar radiation. Table 3 shows that the highest specific weight is hulled irons, so this kind of irons is recommended as the raw materials for cast concrete functioning to absorb the heat from solar radiation.

Table 3. Results of testing the specific weight of types of irons, hardness and content of water

\begin{tabular}{|l|c|c|c|c|c|}
\hline $\begin{array}{c}\text { Grave } \\
\text { origin }\end{array}$ & $\begin{array}{c}\text { Speci } \\
\text { fic } \\
\text { Weig } \\
\text { ht }\end{array}$ & $\begin{array}{c}\text { Absorpt } \\
\text { on }(\%)\end{array}$ & $\begin{array}{c}\text { Value } \\
\text { of } \\
\text { Hardn } \\
\text { ess (\%) }\end{array}$ & $\begin{array}{c}\text { Content } \\
\text { of Water } \\
(\%)\end{array}$ & $\begin{array}{c}\text { Explanati } \\
\text { on }\end{array}$ \\
\hline $\begin{array}{l}\text { Hulled } \\
\text { Iron }\end{array}$ & 2.72 & 1.08 & 2.2 & 0.8 & Very good \\
\hline $\begin{array}{l}\text { Cave } \\
\text { Iron }\end{array}$ & 2.46 & 6.8 & 28 & 4.8 & $\begin{array}{c}\text { Not } \\
\text { enough } \\
\text { good }\end{array}$ \\
\hline $\begin{array}{l}\text { Stone } \\
\text { from } \\
\text { Lumaja } \\
\text { ng }\end{array}$ & 2.42 & 7.8 & 29.6 & 5.2 & $\begin{array}{c}\text { Not } \\
\text { enough } \\
\text { good }\end{array}$ \\
\hline $\begin{array}{l}\text { Stone } \\
\text { from } \\
\text { Tumpa } \\
\text { ng }\end{array}$ & 2.42 & 7.65 & 28.8 & 5.6 & $\begin{array}{c}\text { Not } \\
\text { enough } \\
\text { good }\end{array}$ \\
\hline
\end{tabular}

\section{Testing of Specific Weight and Quality of Cement}

This test was intended to obtaine the type of high quality cement. Table 4 shows the highest specific weight is PCC Gresik, followed by PCC-Puger Jember. The function of cement is to bind aggregate grains to form a solid mass and to fill air spaces among the grain aggregate. Altohough the composition of cement in concrete is merely around $10 \%$, since it is as a binder, cement plays a very important role. Therefore, it is recommended to use cement Puger for constructing cast concrete.

Table 4. Specific Weiht and Quality of Cement

\begin{tabular}{|c|c|c|c|c|c|c|}
\hline \multirow[b]{2}{*}{$\begin{array}{l}\text { Type of } \\
\text { PCC } \\
\text { Cement }\end{array}$} & \multicolumn{2}{|c|}{$\begin{array}{c}\text { Fineness } \\
(\%)\end{array}$} & \multirow[b]{2}{*}{$\begin{array}{c}\text { Spe } \\
\text { cifi } \\
\text { c } \\
\text { Wei } \\
\text { ght } \\
(\mathrm{gr} / \\
\mathrm{cm}^{3} \\
\text { ) }\end{array}$} & \multirow[b]{2}{*}{$\begin{array}{l}\text { Nor } \\
\text { mal } \\
\text { Con } \\
\text { sist } \\
\text { enc } \\
y \\
(\%)\end{array}$} & \multirow[b]{2}{*}{$\begin{array}{c}\text { Sett } \\
\text { ing } \\
\text { Tim } \\
\mathrm{e} \\
(\mathrm{Mi} \\
\text { nute } \\
\text { ) }\end{array}$} & \multirow{2}{*}{$\begin{array}{c}\text { Powe } \\
\text { r of } \\
\text { Morta } \\
r \\
\text { Press } \\
\text { ure \% } \\
(7 \\
\text { day) } \\
(\mathrm{kg} / \\
\left.\mathrm{cm}^{2}\right)\end{array}$} \\
\hline & $\begin{array}{l}\varnothing \\
0 . \\
15 \\
\mathrm{~m} \\
\mathrm{~m}\end{array}$ & $\begin{array}{c}\varnothing \\
0.07 \\
5 \\
\mathrm{~mm}\end{array}$ & & & & \\
\hline Gresik & 0 & $\begin{array}{l}5- \\
10\end{array}$ & 3.16 & $\begin{array}{l}24- \\
26.5\end{array}$ & $\begin{array}{l}60- \\
75\end{array}$ & $\begin{array}{l}175- \\
250\end{array}$ \\
\hline
\end{tabular}

\begin{tabular}{|c|c|c|c|c|c|c|}
\hline $\begin{array}{c}\text { Puger- } \\
\text { Jember }\end{array}$ & 0 & $\begin{array}{c}3- \\
10\end{array}$ & 3.1 & $\begin{array}{c}26- \\
28\end{array}$ & $\begin{array}{c}75- \\
100\end{array}$ & $\begin{array}{c}200- \\
300\end{array}$ \\
\hline $\begin{array}{c}\text { Tiga } \\
\text { Roda }\end{array}$ & 0 & $\begin{array}{c}6- \\
15\end{array}$ & $\begin{array}{c}3.12 \\
-\end{array}$ & $\begin{array}{c}27- \\
29\end{array}$ & $\begin{array}{c}75- \\
105\end{array}$ & $\begin{array}{c}130- \\
200\end{array}$ \\
\hline Holcim & $\begin{array}{c}0- \\
4\end{array}$ & $\begin{array}{c}6- \\
15\end{array}$ & $\begin{array}{c}3.09 \\
2\end{array}$ & $\begin{array}{c}24.8 \\
9\end{array}$ & $\begin{array}{c}30- \\
75\end{array}$ & $\begin{array}{c}120- \\
175\end{array}$ \\
\hline
\end{tabular}

Explanation :

Specification Standart of cement : SNI 15-0302-2004

Testing method standart of cement SNI 15-2049-2004

1. The fineness of cement follows the standart of ASTM C 184-66 it is fine if all the cement may pass the sieve of $\varnothing 0.15 \mathrm{~mm}$, maximumly $22 \%$ does not pass the sieve of $\varnothing 0.075$ mm (ASTM C 184-66)

2. Standart specific weight of cement is $3.15 \mathrm{gr} / \mathrm{cm} 3$ (ASTM C 188-44)

3 . The value of the Standart normal consistency is 24$32 \%$ (Normal Consistency means the plastic condition of the mixture of cement and water (ASTM C 187-71)

4. Setting time is time needed for the cement to be solid after being mixed with water (ASTM C191-71)

5. Mortar Pressure Power is the ability of the mixture of mortar (cement, water and sand) to receive load at the standart age of 3, 7 and 28 days. (ASTM C114-69)

\section{B. Testing of Heat Affordability of Basic}

\section{Materials for Cast Concrete}

The testing of heat affordability was made by giving heat treatment in the raw materials for cast concrete in the electrical hearth and what is measured is heat-absorption ability (temperature) and heat reduction (temperature). The temperature is made by taking the materials out of the hearth after a certian temperature is reached, and in each minute upt to ten minutes a measurement is done.

\section{Testing the Heat-Affordability of Sand}

The data on the heat affordability of sand is graphically presented in Figure 4.

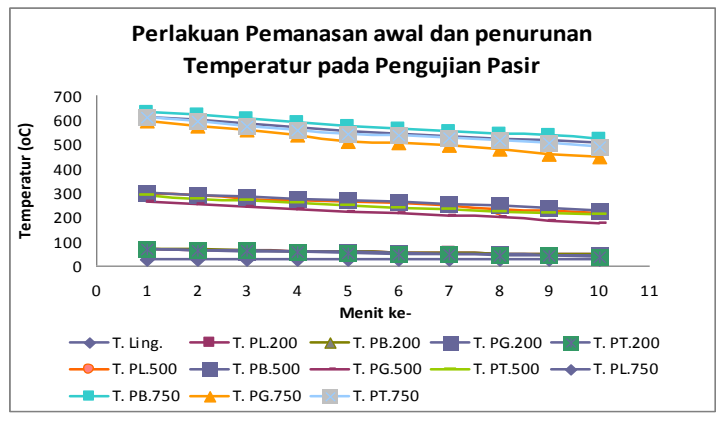

Explanation::

.T.Ling $=$ Surrounding Temperature T.PL $=$ Temperature of Sand from Lumajang 
T.PB $=$ Temperature if Iron Sand

T.PT $=$ Temperature of Sand from Tumpang

T.PG $=$ Temperature Graving/Cave Sand

$200=$ Heating up to $200 \mathrm{oC}$

$500=$ Heating up to $500 \mathrm{oC}$

$750=$ Heating up to $750 \mathrm{oC}$

Figure 4. Treatment of Head affordability of sand

From the Figure, it is shown that the highest absroption of temperature and the slowest temperature reduction is possessed by the type of iron sand. This condition is caused by the metal content in the hard core. Therefore, although this type of sand is finer, but more solid and more heavy.

\section{Testing of Heat Affordability of Cast Iron}

Figure 5 presents the data on the heat affordability of cast stone

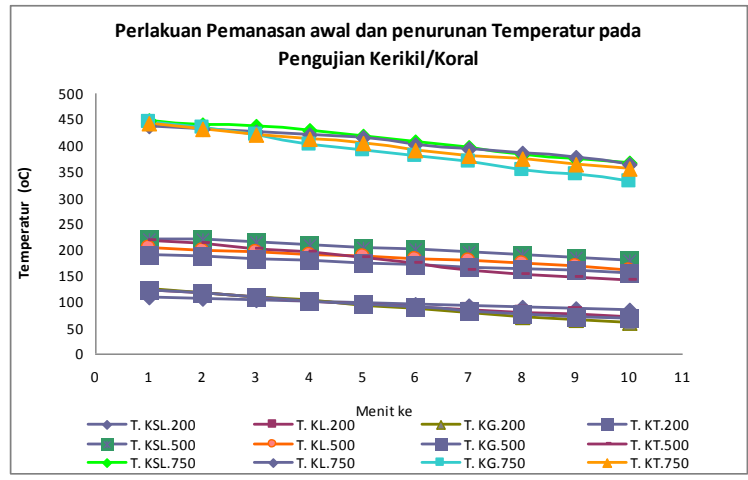

Explanation:

T.Ling $=$ Surrounding Temperature

$\mathrm{T} . \mathrm{KSL}=$ Temperature of gravels/hulled cast stone

$\mathrm{T} . \mathrm{KL}=$ Temperature of Cast stone from Lumajang

$\mathrm{T} . \mathrm{KT}=$ Temperature of cast stone from Tumpang

$\mathrm{T} . \mathrm{KG}=$ emperature of graveling/cave cast stonme

$200=$ Heating up to $200 \mathrm{oC}$

$500=$ Heating up to $500 \mathrm{oC}$

$750=$ Heating up to $750 \mathrm{oC}$

Figure 5. Treatment of heat-affordability of cast stone

Figure 5 shows that hulled cast stone has the highest ability to absorb heat and also posseses the slowest reduction in temperature. This condition is caused by the solidity of the stone.

\section{Testing of Heat-Affordability of Cement}

In figure 6 , data on the test results of heat-affordability of cement are presented.

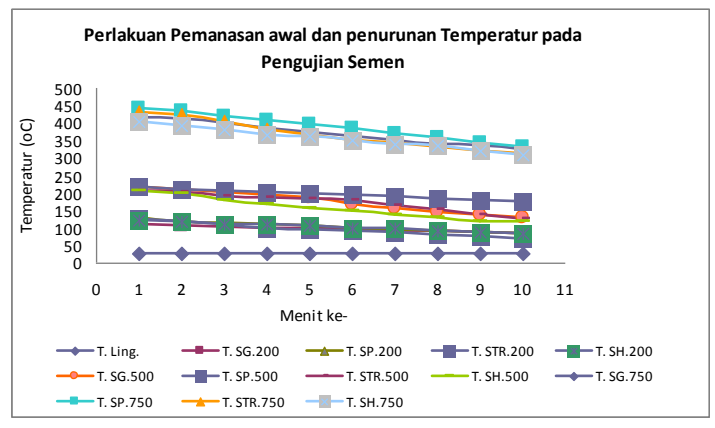

Explanation::

T.Ling=Surrounding Temperature

T.SG=Temperature of cemen Gresik

T.SP=Temperature of cemen Puger-Jember

T.STR $=$ Temperature of cemen Tigaroda

$\mathrm{T} . \mathrm{SH}=$ Temperatur of Semen Holcim

$200=$ Heating up to $200 \mathrm{oC}$

$500=$ Heating up to $500 \mathrm{oC}$

$750=$ Heating up to $750 \mathrm{oC}$

Figure 6. Treatment of heat-affordability of cement

In the figure above, it is known that cement-Puger Jember has the highest ability in absorbing heat and also has the slowest reduction of temperature. Therefore, it is recommended to use the cement for the cast concrete functioning to absrob heat from solar radiation.

\section{Testing of Solar Radiation Absorption of}

\section{Materials for Cast Concrete}

The testing of materials for cast concrete in absorping the heat from solar radiation was made in the Solar and Alternative Energies Lab, Machine Engineering Departmen, Brawijaya Unievrsity of Malang. The testing was under direct solar radiation. The tested material was isolated in a glass room and coated with stereofoam. The volume of the materials for each raw material is $15 \mathrm{cms} \mathrm{x}$ $15 \mathrm{cms}$ x $15 \mathrm{cms}$.

\section{Testing of Solar Radiation Absorption of}

\section{Cement}

The testing of PCC cement was done to 4 (four) types of trademarks namely Semen Gresik (SG), Semen Tigaroda (STR), Semen Holcim (SH) and Semen Puger (SP). The obtained data are temperature of cement, of cover glass (Tc) and of surrounding (T.Ling). 


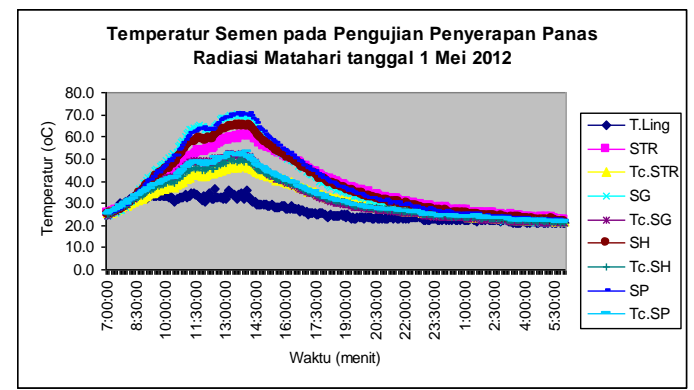

(a)

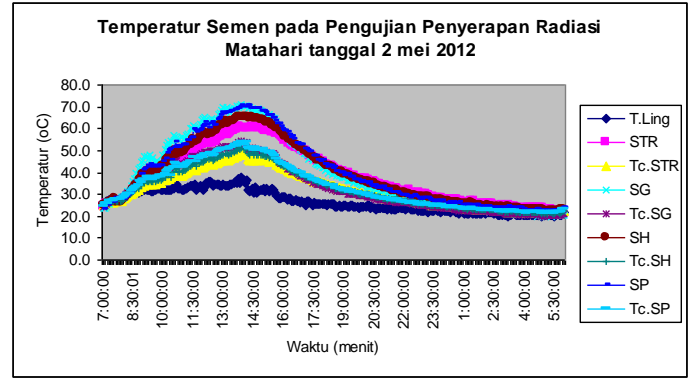

(b)

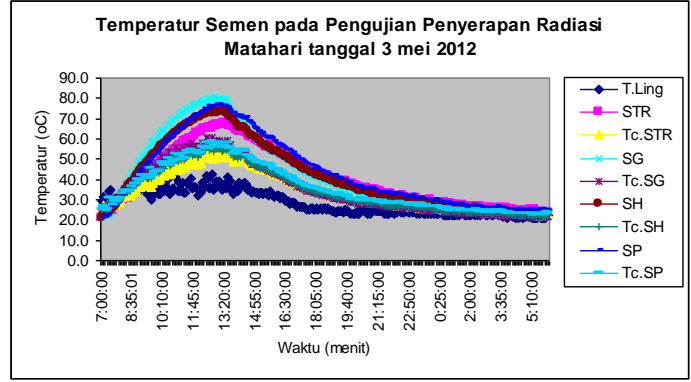

(c)

Figure 7. Graphic of the relationship of cement and time of the etsting of heat absorption of solar radiation

The graphic shows that all types of cements have the same pattern. The temperature of Semen Gresik from early in morning to afternoon showed the highest, but in the late afternoon up to early in the morning in the next day, the highest temperature was occupied by Semen Puger and Semen Tigaroda. So, Semen Gresik has a good heat absorption and posseses low temperature storage. Fron the function of cement as glue and space substitution in cast concrete, and also as heat absorber and keeper, the used cemen should have characteristics of absorbing and keeping heat well.

At average. The highest temperature obtained from the testing of heat absorption and storage identified from the temperature measurement, Semen Puger-Jember occupied the highest capability than Semen Gresik, Semen Tigaroda and Semen Holcim. Therefore, Semen Puger-Jember is recommended to be used for concrete with heat absorption and storage.

\section{Testing of Solar Radiation of Sand}

Testing was made for 4 (four) types of sands namely Pasir from Lumajang (PLjg), Pasir from Tumpang (PTpg), Graving Sand (PG) and Iron Sand (PB). The obtained data are the temperatures of sand (TP), cover glass (TC) and of surorunding (TLing).

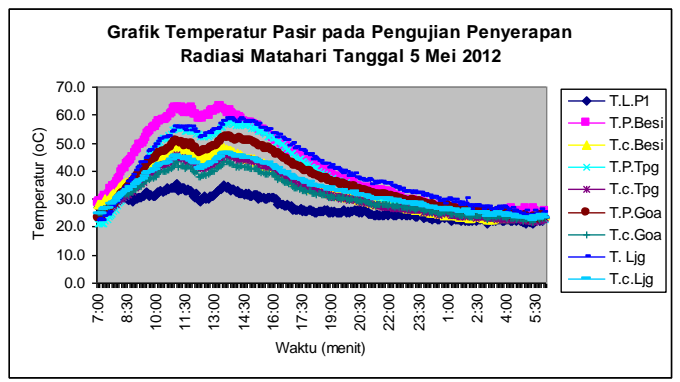

(a)

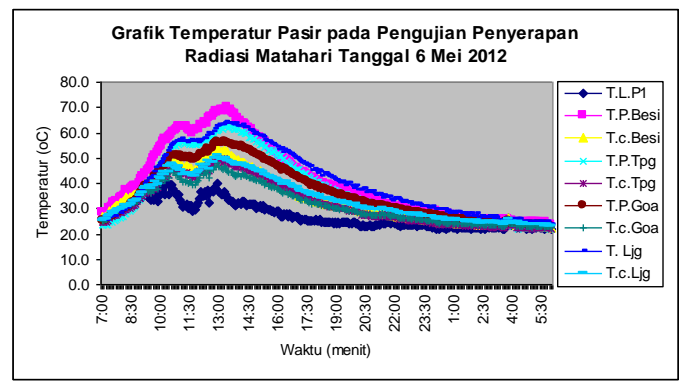

(b)

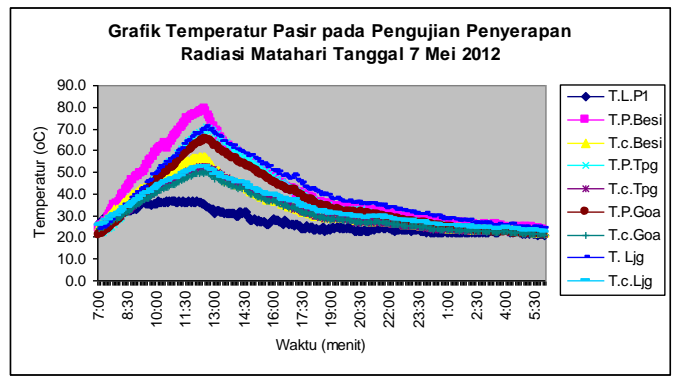

(c)

Figure 8. A Graphic of the relationship between the temperature of sand and the time of testing the heatabsorption of solar radiation.

From the above Graphics, the temperatures of all types of sands showed the same pattern. The temperature of Iron sand, from early in the morning up to afternoon, was in the higest position, but from afternoon up to early morning in the next day, the highest temperature was shown by the and from Lumajang. Therefore, the iron sand possesses good heat-absorption and lower heatstorage. Functionally, aggregate of fine materials is material for filling cast concrete in the form of grain with the size of less than $4,75 \mathrm{~mm}$. it is this function that sand is important as material for cast concrete. The cast 
concrete is then as heat absorber and saver, so that the used sand should be able to absorb and to store heat well.

From the the results of testing in terms of the capability in absorbing and storing heat, iron sand is the best from all. Therefore, this type of sand is recommended to be used for cast concrete serving as heat absorption and storage.

\section{Testing of Solar Radiation Absorption of Cast}

\section{Concrete}

Testing was made for four types of corals namely coral from Lumajang, (KLjg), that from Tumpang (KTpg),Graving/cave coral (KG) adn Hulled corals (KBelah). The obtained data were on the temperature of the coral (TK), of cover glass (TC) and of surrounding (TLing).

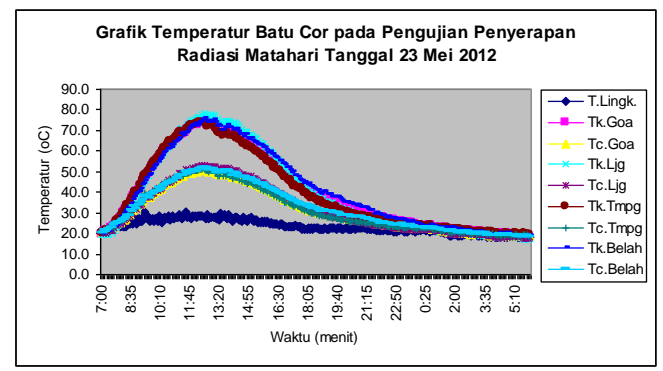

(a)

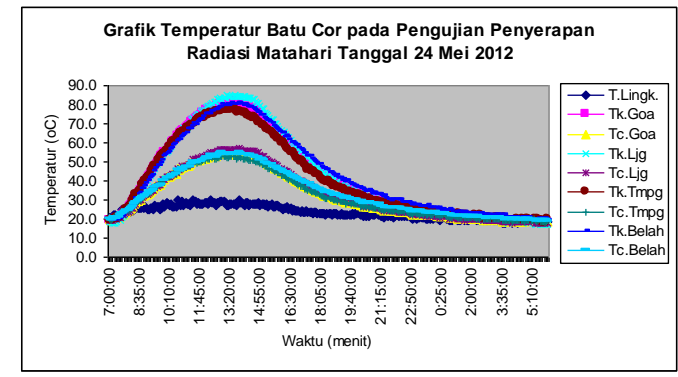

(b)

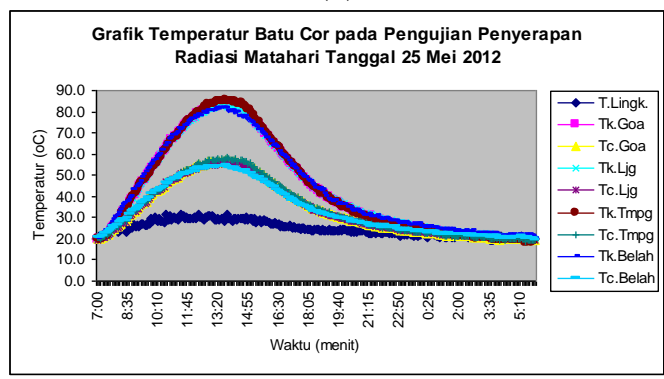

(c)

Figure 9. The Graphic of the relationship between the temperature and the time in testing the heat absorption of solar radiation of cast concrete

The above graphic shows that the temperature of all types of cast stones has the same pattern. The Iron corals show the highest temperature from early in the morning to afternoon, but from late afternoon up to early morning in the next day, the highest temperature was shown by the coral from Lumajang. Therefore, Iron corals posses good heat absorption and lower heat storage. Functionally, hard aggregatesare the main materials for fillers of the cast concretes in the form of grains with the size of more than $4,75 \mathrm{~mm}$. It is this function the makes the corals important for cast concretes. The concretes are then used for heat absorber and storage.

From the results of the testing, it is shown that hulled corals have higher capability in absorbing and storing heat than other types of corals.

\section{Discussion}

From the data and graphics, basic materials for cast concrete as heat-absorber sheet from solar radiation can be disccused as follows.

1. Sand is a fine serving as cast concrete filler. Hopefully, this concrete is able to absorb and to store heat well. The function of sand is expected to absorb heat from solar radiation, to resist the temperature of $\pm 100{ }^{\circ} \mathrm{C}$, to fill in the cast concrete structure well, and to restrain pressure. Iron sand is the one that is able to absorb and to store solar radiation well due to its high specific weight, thicker black color, and more solid in a certain volume. The sand with similar characteristic with those of iron sand is the sand from Lumajang, but its grains are bigger, so that there still a lot of spaces in a certain volume. The sand from Lumajang results in such high enough spaces that it cannot absorb heat well. Sand from Tumpang and graveling sand posses lower specific weight, a lot of spaces, and also of mud layers although it has been washed and this results in lower quality.

2. Gravels are the main materials for cast concrete, so they are very important for making cast concrete structures. Moreover, the gravels should be able to absorb and store heat well. Gravels with hulled type have the highest specific weight, are able to afford heat, and to absorb and to store higher heat than others. This is because the structure of this gravel is more solid and is black in color.

3. Cement is glue material and functions to fill in spaces in cast concrete. In this case, cement servs to absorb and store heat from solar radiation. The best cement is that with the trademark of Semen PugerJember, since this cement has better results in terms of mortar pressure, head affordability and heat absorption and storage from solar radiation tests than other cement such as Semen Gresik, Semen Tigaroda and Semen Holcim. For the highest specific weight, Sement Gresik is the best. Cement later will be a part of cast concrete structure functioning as hear absorber sheet, it is the Semen- 
Puger Jember that is the main choice as substitution materials and glue for cast concrete funcitoning as heatabsorber sheet.

\section{CONCLUSIONS}

From the research results, some conclusions can be made:

1. The best type of sand is that of iron sand; from the specific weight, heat-affordability treatment, and heat absorption and storage of solar radiation than sand from Lumajang, from Tumpang and tekangraving sand.

2. The best type of corals is that of hulled stones. This type of corals is also better than those from Lumajang, Tumang and graving coral in terms of specific weight, heataffordability, heat absorption and storage from solar radiation.

3. The best type of cement trademark is Semen Puger-Jember than Semen Gresik, Semen Tigaroda and Semen Holcimm in terms of specific weight, heat-affordability, heat absorption and storage from solar radiation.

\section{REFFERENCES}

[1] Duffie J.A. dan Beckman W.A. (1980). Solar Engineering Of Thermal Processes. New York: John Willey \& Sons.

[2] Ismail N. R., (2007), Pengaruh jenis pelat penyerap dan laju aliran terhadap kinerja solar heater sederhana. PHK-A2. Teknik Mesin

[3] Ismail N. R., dan Aditya C. (2010), Pengaruh komposisi kolektor beton cor dan ketebalan terhadap efisiensi penyerapan panas. PDM DIKTI, Jakarta.

[4]. Lermpoy K.A. (2003), "Pilot proyek basin tipe solar still dipesisir Probolinggo", Tesis. Malang. Program Pascasarjana Teknik Mesin Univ. Brawijaya Malang.

[5] Monintja Nita C. V.(2004). "Usaha-usaha untuk meningkatkan efisiensi dan produktifitas solar still”. Thesis. Malang: Program Pascasarjana Jurusan Teknik Mesin Unibraw Malang.

[6] Rahmad Subarkah, (2001), "Penelitian absorber solar still untuk distilasi air laut", Skripsi, Malang: Jurusan Teknik Mesin FT Unibraw Malang 